\title{
Papers
}

\section{Effect of smoke-free workplaces on smoking behaviour: systematic review}

\author{
Caroline M Fichtenberg, Stanton A Glantz
}

\begin{abstract}
Objective To quantify the effects of smoke-free workplaces on smoking in employees and compare these effects to those achieved through tax increases. Design Systematic review with a random effects meta-analysis.

Study selection 26 studies on the effects of smoke-free workplaces.

Setting Workplaces in the United States, Australia, Canada, and Germany.

Participants Employees in unrestricted and totally smoke-free workplaces.

Main outcome measures Daily cigarette consumption (per smoker and per employee) and smoking prevalence.

Results Totally smoke-free workplaces are associated with reductions in prevalence of smoking of 3.8\% (95\% confidence interval $2.8 \%$ to $4.7 \%$ ) and 3.1 (2.4 to 3.8) fewer cigarettes smoked per day per continuing smoker. Combination of the effects of reduced prevalence and lower consumption per continuing smoker yields a mean reduction of 1.3 cigarettes per day per employee, which corresponds to a relative reduction of $29 \%$. To achieve similar reductions the tax on a pack of cigarettes would have to increase from $\$ 0.76$ to $\$ 3.05$ ( $€ 0.78$ to $€ 3.14$ ) in the United States and from $£ 3.44$ to $£ 6.59$ (€5.32 to €10.20) in the United Kingdom. If all workplaces became smoke-free, consumption per capita in the entire population would drop by $4.5 \%$ in the United States and $7.6 \%$ in the United Kingdom, costing the tobacco industry $\$ 1.7$ billion and $£ 310$ million annually in lost sales. To achieve similar reductions tax per pack would have to increase to $\$ 1.11$ and $£ 4.26$.
\end{abstract}

Conclusions Smoke-free workplaces not only protect non-smokers from the dangers of passive smoking, they also encourage smokers to quit or to reduce consumption.

\section{Introduction}

Passive smoking is linked with cancer, heart disease, respiratory illness ${ }^{12}$ and is the leading source of indoor air pollution. ${ }^{3}$ In the United States, passive smoking has been linked to the deaths of at least 53000 non-smokers each year, about one non-smoker for each eight smokers that tobacco kills. ${ }^{24}$ By August 2001, 234 US communities had enacted local ordinances that required all workplaces to be completely smoke-free (185 communities included restaurants; American Nonsmokers' Rights Foundation, local ordinance database), and many businesses implemented voluntary policies creating smoke-free workplaces. By 1998-9, 69\% of US workers employed indoors outside the home had smoke-free workplaces. ${ }^{5}$

Smoke-free workplaces not only protect nonsmokers, they also create an environment that encourages smokers to cut back ${ }^{6}$ or quit. Since as early as the 1980 s the tobacco industry has recognised that smokefree workplaces have a major effect on cigarette consumption. ${ }^{7}$ In 1992 Phillip Morris Tobacco Company privately estimated that if all workplaces were smoke-free, total consumption would drop about $10 \%$, through a combination of quitting and cutting down. ${ }^{8}$

Estimating the effect of creating smoke-free workplaces on total cigarette consumption is important because many places are implementing tobacco control programmes with money from dedicated $\operatorname{taxes}^{9-18}$ or with funds from the settlement of lawsuits against the tobacco industry. ${ }^{19}$ There are many potential elements of such a programme, including increased taxes, legislation on smoke-free workplaces and public places, mass media education programmes, youth access laws, school based programmes, community programmes, and cessation assistance. ${ }^{20-22}$ Outside the United States, restriction of tobacco advertising is also an option. A quantitative comparison of the effects of these interventions would enable public health policy makers to make maximum use of the (usually limited) funds available for tobacco control.

We investigated the effects of smoke-free workplaces on cigarette consumption and compared these effects with those obtained by raising taxes.

\section{Methods}

\section{Study selection}

We located studies on the effects of totally smoke-free workplaces on prevalence of smoking and daily cigarette consumption through Medline, Science Citation Index, Social Sciences Citation Index, Current Contents, and PsychInfo; from reviews ${ }^{621} 23$ 24; and from references in the papers we located.

We included 26 studies reported in 24 papers. Worksite studies measured changes in smoking that accompanied regulations in individual workplaces
Editorial by West

Center for Tobacco Control Research and Education, Institute for Health Policy Studies, Cardiovascular Research Institute, University of California,

San Francisco, San Francisco, CA 94143, USA Caroline M Fichtenberg research fellow Stanton A Glantz professor of medicine

Correspondence to: S A Glantz glantz@medicine. ucsf.edu

bmj.com 2002;325:188 
assessed prospectively, ${ }^{25-32}$ in sequential cross sections, ${ }^{26}{ }^{33-38}$ or retrospectively. ${ }^{37}{ }^{39-43}$ Population studies compared behaviour of smokers employed in workplaces with differing smoking policies and were cross sectional. ${ }^{44-48}$

We excluded a further 16 studies because they evaluated policies that were not totally smoke-free ${ }^{49-64}$ and 11 others because they did not report the desired outcomes. ${ }^{556-74}$ We excluded one study because the surveys carried out before and after the non-smoking policy were separated by eight years, so results could be contaminated by confounding factors. ${ }^{75}$

\section{Data analysis}

We computed differences in consumption (per smoker and per employee) and prevalence before and after workplaces became smoke-free (in workplace studies) or between comparable samples with and without regulations (in population studies).

Using $t$ tests we found that workplace and population studies did not yield different effects $(\mathrm{P}>0.2) \cdot{ }^{76} \mathrm{We}$ compared the results from different study designs with analysis of variance. Sequential cross sectional studies yielded significantly smaller changes in number of cigarettes per smoker than the other study designs $(\mathrm{P}=0.003)$, but there were no significant differences among the study types for prevalence $(\mathrm{P}=0.081)$, consumption per employee $(\mathrm{P}=0.219)$, or relative change in consumption $(\mathrm{P}=0.143)$. We therefore pooled all studies in a random effects meta-analysis. ${ }^{76}$

If standard errors for consumption and prevalence change were not reported we estimated them (see table 1). We did not conduct a meta-analysis for the consumption per employee because we could not compute the standard errors necessary for the meta-analysis. There was no evidence of publication bias as assessed with funnel plots (figure).

\section{Results}

\section{Effects of smoke-free workplaces}

Implementation of totally smoke-free workplace policies was associated with a reduction in absolute prevalence of 3.8\% (95\% confidence interval 2.8\% to $4.7 \%$ ) and a decrease in consumption of 3.1 (2.4 to 3.8) cigarettes per day per continuing smoker (table 1). Combination of the effects of stopping smoking (lower prevalence) and the lower consumption per continuing smoker means that 1.3 (range 0.2-1.8) fewer

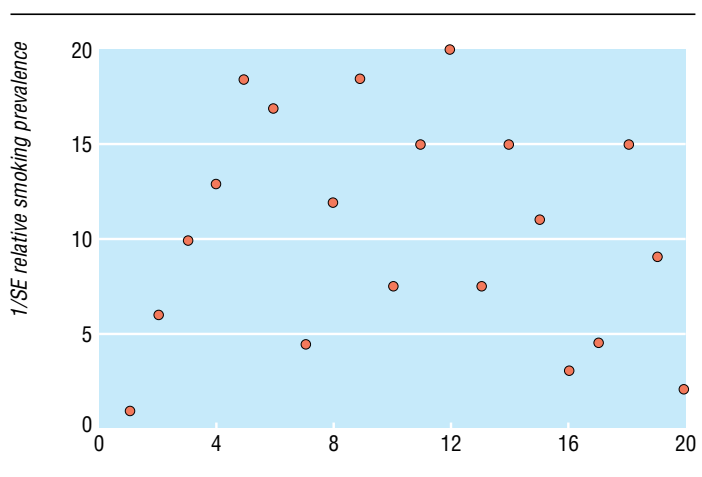

Relative change in smoking prevalence (\%)

Funnel plot used to assess publication bias cigarettes were smoked per day per employee (smokers and non-smokers), which corresponds to a 29\% (11\%$53 \%$ ) relative reduction.

The time between implementation of the totally smoke-free workplace policies and the follow up survey ranged from 1 to 24 months (mean 10 months, median 9 months) in the 21 workplace studies. This sample size has an $80 \%$ power for detecting a correlation of plus or minus 0.064 . The correlation between length of follow up and effect was not significant (prevalence $r=0.08, \mathrm{P}=0.75$; consumption per smoker $r=0.45, \mathrm{P}=0.09$; consumption per employee $r=0.28$, $\mathrm{P}=0.43$ ). The effects of smoke-free workplaces after they were implemented remained stable over time.

\section{Comparison with tax increases}

Increasing the price of cigarettes by $10 \%$ leads to a $4 \%$ reduction in consumption per capita (which reflects changes in both consumption per smoker and prevalence). ${ }^{23}$ To obtain the $29 \%$ drop in employee consumption resulting from smoke-free workplaces would require an increase in the price of cigarettes of $73 \%(29 \% / 0.4)$. Such an increase would require the average tax per pack to be increased from $\$ 0.76$ to $\$ 3.05$ in the United States and from $£ 3.44$ to $£ 6.59$ in the United Kingdom (table 2).

The effect of workplace policies on consumption in the general population will be equivalent to a smaller tax increase because making workplaces smoke-free affects only those employed indoors and outside the home (about half of the US adult population ${ }^{78}$ ) and whose workplaces are not already smoke-free $(31 \%$ in the United States ${ }^{5}$ and 52\% in the United Kingdom ${ }^{80}$ ), while tax increases will affect all tobacco buyers. The marginal effect on the entire population of making all workplaces smoke-free would be a reduction in per capita cigarette consumption of $4.5 \%$ in the United States and $7.6 \%$ in the United Kingdom. To achieve these reductions would require an increase in tax from $\$ 0.76$ to $\$ 1.11$ per pack in the United States and from $£ 3.44$ to $£ 4.26$ in the United Kingdom (table 2).

\section{Effect on tobacco company revenues}

In the United States about 103 million people are employed indoors outside the home, ${ }^{78} 7969 \%$ of whom are already in smoke-free workplaces. ${ }^{5}$ The marginal effect of the remaining workplaces becoming smokefree would be 40 million fewer cigarettes smoked per day (103 million $\times 31 \% \times-1.3$ cigarettes per day per employee). In the United States in 2000 the average pretax price for 20 cigarettes was $\$ 2.36^{81}$ so this reduced consumption would cost the tobacco industry \$1.7bn per year in lost sales. Likewise in the United Kingdom 29.9 million people are employed indoors, ${ }^{82}$ with $48 \%$ already working in smoke-free workplaces. In 2001 the pretax price of 20 Marlboro cigarettes was $£ 0.86$ (Clive Bates, personal communication) so the marginal effect of all work sites becoming smoke-free would be 20 million fewer cigarettes smoked per day, worth $£ 310 \mathrm{~m}$ a year to the tobacco industry.

\section{Discussion}

In this review we found that smoke-free workplaces are associated with a decrease in prevalence of tobacco consumption of nearly $4 \%$, a decrease not due to 
underlying secular trends in prevalence. From 1987 to 1995 prevalence in the United States fell at about $0.46 \%$ per year, ${ }^{83}$ and the follow up time for the studies we analysed was generally less than one year. Our results for consumption per smoker (3.1 fewer cigarettes per day) are comparable with those of Chapman et al, ${ }^{6}$ who estimated that smoke-free policies were associated with a fall in consumption of 3.5 cigarettes per day per continuing smoker. They did not quantify effects on prevalence.
Totally smoke-free workplaces versus smoke-free areas

Three of the population studies allowed us to compare the effects of totally smoke-free policies with those of partially smoke-free policies (where smoking is allowed in some areas other than work areas) (table 3). ${ }^{45} 4648$ Totally smoke-free workplaces had about twice the effect on consumption and prevalence as policies that allowed smoking in some areas. Internal research at Phillip Morris reached similar conclusions in 1992:

Table 1 Summary of studies of effects of smoke-free workplace policies on cigarette consumption and prevalence of smoking

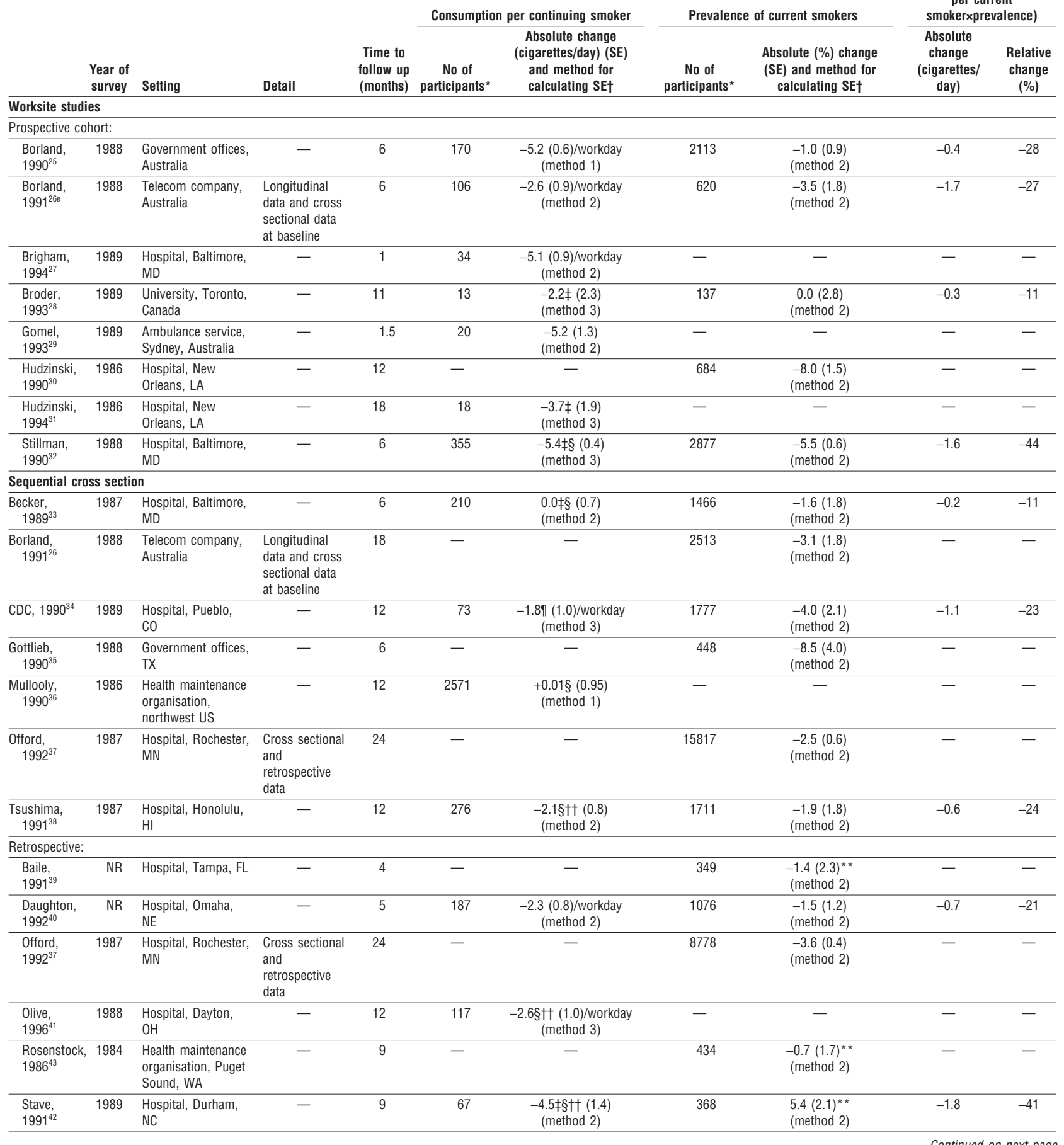


Table 1 Summary of studies of effects of smoke-free workplace policies on cigarette consumption and prevalence of smoking—continued from previous page

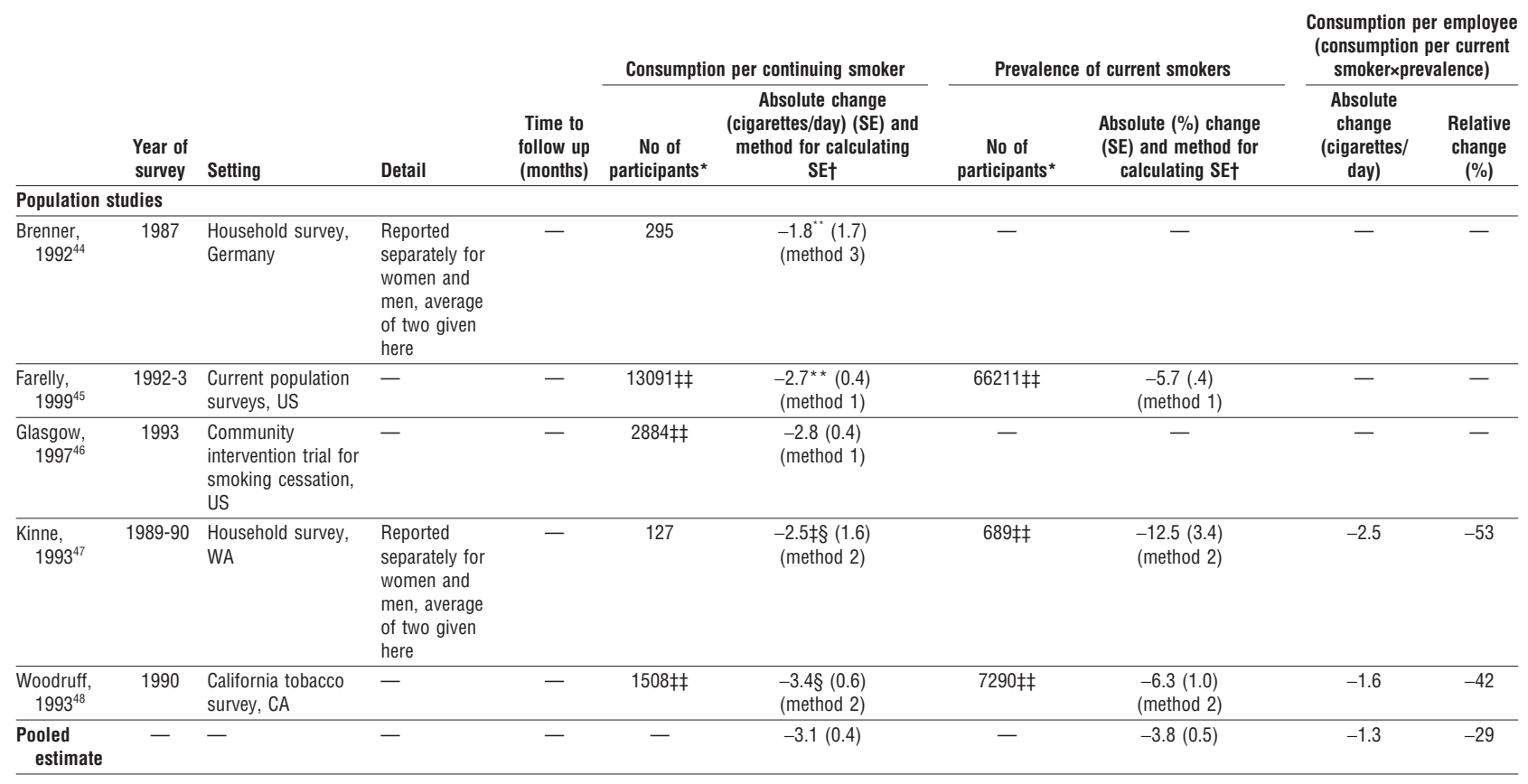

$\mathrm{NR}=$ not reported.

${ }^{*}$ Cohort size for longitudinal studies (allowing for loss to follow up) or sum of two samples for cross sectional studies.

tMethod: 1-SE or $95 \% \mathrm{Cl}$ for change reported in the paper; 2-SE calculated based on average of SD of unrestricted and smoke-free estimates; $3-\mathrm{SE}$ calculated based on average of SD

estimates generated by methods 1 and 2 from other studies of same type. For methods 2 and 3 , SE estimates calculated as $\sqrt{ }\left(S^{2} / n\right)$ where $n$ is size of cohort (allowing for loss to follow up)

for longitudinal studies and $\sqrt{ }\left(S D^{2} /\left(1 / n_{1}+1 / n_{2}\right)\right)$ where $n_{1}$ and $n_{2}$ are two sample sizes for cross sectional analyses.

$\ddagger$ Average of workday and leisure day consumption estimates ((5×workday+2×leisure $) / 7)$.

§Per current smoker (smoker at time of survey) rather than continuing smoker (smoker at both baseline and follow up).

१Cohort of smokers.

** Estimated from initiation and cessation rates.

††Reported consumption as categorical variable; converted here to continuous variable by using midpoints.

¥†Sample sizes computed by multiplying total sample size by proportions of individuals in smoke-free and unrestricted workplaces.

"Milder workplace restrictions, such as smoking only in designated areas, have much less impact on quitting rates [than totally smoke-free workplaces] and very little impact on consumption."

\section{Effects of legislation}

To protect the health of non-smokers US local and state governments have enforced legislation restricting smoking in public and in workplaces. Seven studies reported the effects of these laws on adult consumption or prevalence. ${ }^{84-90}$ The five studies that characterised laws according to extensiveness of their coverage found decreases in consumption per capita or prevalence associated with more extensive laws compared with no laws ranging from 0.16 to 0.73 fewer cigarettes per day per capita and $3.7 \%$ to $4.5 \%$ reduction in absolute prevalence. ${ }^{84} 86-8890$

Local clean air laws are stronger and more comprehensive than state legislation. ${ }^{91}$ Strong local ordinances in California in 1990-1 were associated with an absolute quit rate (over the previous six months) $7.6 \%$ higher than in areas with no workplace laws. ${ }^{86}$ A Canadian study in $1990-1$ found a $21 \%$ reduction in the odds of being a smoker in areas with high versus low coverage of smoking bylaws. ${ }^{89}$ A 1995 Finnish law that prohibited smoking in public areas in workplaces (with the option of creating separately ventilated smoking rooms) was associated with a $4.5 \%$ drop in prevalence of smoking and three fewer

Table 2 Price and tax changes necessary to obtain same effect as smoke-free workplaces

\begin{tabular}{|c|c|c|c|c|c|c|}
\hline \multirow[b]{2}{*}{ Location } & \multirow{2}{*}{$\begin{array}{l}\text { Effect of smoke-free } \\
\text { workplace on } \\
\text { consumption }\end{array}$} & \multicolumn{2}{|c|}{ Equivalent price effect (per pack) } & \multirow[b]{2}{*}{ Price/tax increase } & \multicolumn{2}{|c|}{ Equivalent tax effect (per pack) } \\
\hline & & Relative change* & Absolute change & & Relative change & Absolute change \\
\hline \multicolumn{7}{|c|}{ Within workplace (consumption/employee) } \\
\hline$\overline{U S}$ & $-29 \% \dagger$ & $+73 \%$ & $\$ 3.12 \ddagger$ to $\$ 5.41$ & $\$ 2.29$ & $+300 \%$ & $\$ 0.76 \neq$ to $\$ 3.05$ \\
\hline UK & $-29 \% \dagger$ & $+73 \%$ & $£ 4.30 \S$ to $£ 7.45$ & $£ 3.15$ & $+92 \%$ & $£ 3.44 \S$ to $£ 6.59$ \\
\hline \multicolumn{7}{|c|}{ In population (consumption/capita) } \\
\hline US & $-4.5 \%$ & $+11 \%$ & $\$ 3.12 \ddagger$ to $\$ 3.47$ & $\$ 0.35$ & $+47 \%$ & $\$ 0.76 \neq$ to $\$ 1.11$ \\
\hline UK & $-7.6 \%$ ף & $+19 \%$ & $£ 4.30 \S$ to $£ 5.12$ & $£ 0.82$ & $+24 \%$ & $£ 3.44 \S$ to $£ 4.26$ \\
\hline
\end{tabular}

Note: Numbers may not add up because of rounding. As of June 2002: $£ 1=\$ 1.50=€ 1.55 ; \$ 1=£ 0.67=€ 1.03$. ${ }^{*}$ Smoke-free workplace effect/price elasticity of cigarette consumption $\left(-0.4^{23}\right)$ (see text). †From table 1.

¥Average price or tax in United States in $2000 .^{81}$

$\S$ Average price or tax for 20 Marlboros in United Kingdom in 2001 (Clive Bates, personal communication).

Effect on consumption per employee of smoke-free workplace $(-29 \%) \times$ proportion employed indoors $\left(50 \%{ }^{78} 79\right) \times$ proportion not yet smoke-free $\left(31 \%{ }^{5}\right)$ for US; for UK figures are $-29 \% \times 50 \%{ }^{78} \times 52 \% .80$ 
Table 3 Comparison of the effects of totally smoke-free versus partially smoke-free workplaces*

\begin{tabular}{|c|c|c|c|c|c|}
\hline \multirow[b]{2}{*}{ Study } & \multirow[b]{2}{*}{ Setting } & \multicolumn{2}{|c|}{ Consumption/smokert } & \multicolumn{2}{|c|}{ Prevalence (\%) } \\
\hline & & $\begin{array}{l}\text { Smoke-free } v \\
\text { unrestricted }\end{array}$ & $\begin{array}{c}\text { Partially smoke-free } v \\
\text { unrestricted }\end{array}$ & $\begin{array}{l}\text { Smoke-free } v \\
\text { unrestricted }\end{array}$ & $\begin{array}{c}\text { Partially smoke-free } v \\
\text { unrestricted }\end{array}$ \\
\hline Woodruff, $1993^{48}$ & 1990 statewide survey of California & -3.3 & -2.8 & $-6.3 \%$ & $-3.5 \%$ \\
\hline Glasgow, $1997^{46}$ & 1993 study of 22 North American communities & -2.8 & -1.2 & NR & NR \\
\hline Farelly, $1999^{45}$ & 1992-93 survey of US workers & -2.7 & -1.5 & $-5.7 \%$ & $-2.6 \%$ \\
\hline
\end{tabular}

NR: Not reported.

*Totally smoke-free workplaces allow no smoking inside buildings, partially smoke-free workplaces allow smoking in designated areas.

†Cigarettes per day.

cigarettes smoked per day among continuing smokers. $^{57}$

\section{Effects of smoke-free workplaces and clean air legislation on teenagers}

Teenagers respond to smoke-free environments by decreasing smoking. One study reported the effects of workplace policies on employed teenagers. ${ }^{92}$ Teenagers who worked in totally smoke-free work sites were $68 \%$ (95\% confidence interval $51 \%$ to $90 \%$ ) as likely to ever smoke than those who worked in less restricted work sites. Eight studies examined the effect of state and local clean air laws on smoking in young people. ${ }^{60}{ }^{93-98}$ Studies that compared the effects of extensive versus no laws found absolute reductions in prevalence of $2.3 \%$ to $46.0 \%,{ }^{96}$ a relative reduction in prevalence of $17.2 \%,{ }^{97}$ and a relative reduction in per capita cigarette consumption of $50.4 \% .^{90}$ Clean air laws can have substantial effects on smoking in teenagers, even though few are employed in ways that directly subject them to the laws.

Voluntary action to make homes smoke-free leads to lower rates of smoking among US high school students (odds ratio $0.79,95 \%$ confidence interval 0.67 to 0.91 , for 30 day prevalence).$^{97}$ Teenagers living in a smoke-free home were $74 \%$ (62\% to $88 \%)$ as likely to ever smoke compared with those who lived in households with no smoking restrictions, after adjustment for demographics and smoking status of other household members. ${ }^{92}$ Among young people aged 14 to 22 years old in the United States the only significant predictor of planning to stop smoking was the belief that passive smoking harms non-smokers; this belief more than doubled the chances of planning to stop or of having stopped already. ${ }^{100}$ These effects, as well as the workplace effects, probably act by reinforcing the social unacceptability of smoking.

As interventions designed to restrict the purchase of cigarettes have no effect on the prevalence of smoking among teenagers, ${ }^{101}$ clean indoor air is an effective strategy for reducing tobacco consumption among teenagers.

\section{Weaknesses of study}

We included studies with different methods carried out in different settings at different points in time. There were, however, no systematic differences in the results obtained in the workplace and population based studies, and the random effects model in the meta-analysis allows for any heterogeneity in study design.

We used changes in consumption per continuing smoker to measure the effect of the policies on consumption. Eight of the studies, however, reported consumption per current smoker (that is, including in the baseline measurement people who quit after the policy was implemented and in the follow up those

\section{What is already known on this topic}

Smoke-free workplaces are associated with lower cigarette consumption per continuing smoker

\section{What this study adds}

Smoke-free workplaces reduce prevalence of smoking as well as consumption

The combined effects of people stopping smoking and reducing consumption reduces total cigarette consumption by $29 \%$

To achieve similar results through taxation would require cigarette taxes per pack to increase from $\$ 0.76$ to $\$ 3.05$ in the United States and from $£ 3.44$ to $£ 6.59$ in the United Kingdom

who started after the policy). ${ }^{33} 411^{42-48}$ We used these data as consumption per continuing smoker, although there is evidence that those who stop smoked less ${ }^{102103}$ and therefore that changes in consumption among current smokers are smaller on average than those among continuing smokers. We may therefore be underestimating the effect on continuing smokers.

\section{Interpretation of results}

Smoke-free workplaces not only protect non-smokers from passive smoking but also encourage smokers to quit or reduce their consumption, reducing total cigarette consumption per employee by $29 \%$. If all workplaces that are currently not smoke-free in the United States and the United Kingdom were to become smoke-free, consumption per capita (for the entire adult population) would drop by $4.5 \%$ and $7.6 \%$, respectively. Achieving the same result with a tax increase would require a $47 \%$ tax increase in the United States and a 24\% increase in the United Kingdom. While producing benefits for non-smokers by eliminating passive smoking ${ }^{32} 5^{104} 105$ and making it easier for smokers to reduce or stop smoking, smoke-free workplaces substantially reduce tobacco industry sales. This loss in revenues explains why the industry fights so hard against legislation to ensure that workplaces become smoke-free. ${ }^{78} 10$ 106-110

Contributors: Both authors participated in all aspects of the formulation of this project, analysis of the results, and preparation and revision of the manuscript. SAG is guarantor.

Funding: National Cancer Institute Grant CA-61021.

Competing interests: None declared.

1 USDHHS. The health consequences of involuntary smoking. A report of the surgeon general. Washington, DC: US Department of Health and Human Services, Public Health Service, Centers for Disease Control, 1986.

2 National Cancer Institute. Health effects of exposure to environmental tobacco smoke: the report of the California Environmental Protectional Agency. 
Bethesda, MD: National Cancer Institute, 1999 (Smoking and Health Monograph 10).

3 Repace JL, Lowrey AH. Indoor air pollution, tobacco smoke, and public health. Science 1980;208:464-72.

4 Glantz SA, Parmley WW. Passive smoking and heart disease. Epidemiology, physiology, and biochemistry. Circulation 1991;83:1-12.

5 Shopland DR, Gerlach KK, Burns DM, Hartman AM, Gibson JT. State-specific trends in smoke-free workplace policy coverage. The current population survey tobacco use supplement 1993 to 1999. J Occup Environ Med 2001;43:680-6.

6 Chapman S, Borland R, Scollo M, Brownson RC, Dominello A, Woodward S. The impact of smoke-free workplaces on declining cigarette consumption in Australia and the United States. Am J Public Health 1999:89:1018-23.

7 Chilcote S. Public smoking: the problem (SDC Introduction). Tobacco Institute,1985. Bates Range TIMN0014552/4597 www.tobaccoinstitute. com/getimg.asp?pgno $=0 \&$ start $=0 \&$ if $=$ avtidx\&bool $=00145 * \&$ \&docid $=$ TIMN0014554/4565\&docnum $=2 \&$ summary $=0 \&$ sel $1=($ accessed $27 \mathrm{Oct}$ 2001).

8 Heironimus J. Impact of workplace restrictions on consumption an incidence (memo to Louis Suwarna). Phillip Morris, 21 January, 1992: Bates Range $\quad 2045447779 / 7806$ 2045447779_7806.PDF (accessed 27 Oct 2001). try revenues associated with California's Proposition 99. Tob Control 1993;2:311-314

10 Glantz S, Balbach E. Tobacco war: inside the California battles. Berkeley, CA: University of California Press, 2000.

11 Pierce JP, Evans N, Farkas AJ, Cavin SW, Berry C, Kramer M, et al. Tobacco use in California: an evaluation of the tobacco control program, 1989-1993. La Jolla, CA: University of California, San Diego, 1994.

12 Pierce JP, Gilpin EA, Emery SL, White MM, Rosbrook B, Berry C, et al. Has the California tobacco control program reduced smoking? JAMA 1998;280:893-9.

13 Pierce JP, Gilpin EA, Emery SL, Farkas AJ, Zhu SH, Choi WS, et al. Tobacco control in California: who's winning the war? San Diego: University of California, San Diego, 1998.

14 Siegel M, Mowery PD, Pechacek TP, Strauss WJ, Schooley MW, Merritt RK, et al. Trends in adult cigarette smoking in California compared with the rest of the United States, 1978-1994. Am J Public Health 2000;90:372-9.

15 Bal DG, Kizer KW, Felten PG, Mozar HN, Niemeyer D. Reducing tobacco consumption in California. Development of a statewide anti-tobacco use campaign. JAMA 1990;264:1570-4.

16 Traynor MP, Glantz SA. California's tobacco tax initiative: the development and passage of proposition 99. J Health Policy Politics Law $1996 ; 21: 543-85$

17 Fichtenberg CM, Glantz SA. Association of the California tobacco control program with declines in cigarette consumption and mortality from heart disease. N Engl J Med 2000;343:1772-7.

18 Kessler KM. Controlling tobacco use. N Engl J Med 2001;344:1798-9.

19 National Association of Attorneys General. Multistate settlement with the tobacco industry. www.library.ucsf.edu/tobacco/litigation/msa.pdf (accessed 20 Aug 2001).

20 Centers for Disease Control and Prevention. Best practices for comprehensive tobacco control programs. Atlanta, GA: US. Department of Health and Human Services, Centers for Disease Control and Prevention, National Center for Chronic Disease Prevention and Health Promotion, Office on Smoking and Health, 1999.

21 National Cancer Institute. Population based smoking cessation:proceedings of a conference on what works to influence cessation in the general population. Bethesda, MD: US Department of Health and Human Services, National Institutes of Health, National Cancer Institute, 2000 (Smoking and Tobacco Control Monograph No 12).

22 National Cancer Policy Board. State programs can reduce tobacco use. Washington, DC: Institute of Medicine, 2000.

23 US Department of Health and Human Services. Reducing tobacco use: a report of the surgeon general. Atlanta, GA: US Deparment of Health and Human Services, Centers for Disease Control and Prevention, National Center for Chronic Disease Prevention and Health Promotion, Office of Smoking and Health, 2000.

24 Hopkins DP, Briss PA, Ricard CJ, Husten CG, Carande-Kulis VG, Fielding $\mathrm{JE}$, et al. Reviews of evidence regarding interventions to reduce tobacco use and exposure to environmental tobacco smoke. Am I Preo Med 2001;20(2 suppl):16-66

25 Borland R, Chapman S, Owen N, Hill D. Effects of workplace bans on cigarette consumption. Am J Public Health 1990;80;178-80.

26 Borland R, Owen N, Hocking B. Changes in smoking behaviour after a total workplace smoking ban. Aust J Public Health 1991;15:130-4

27 Brigham J, Gross J, Stitzer M, Felch L. Effects of a restricted work-site smoking policy on employees who smoke. Am I Public Health 1994:84:773 -8.

28 Broder I, Pilger C, Corey P. Environment and well-being before and following smoking ban in office buildings. Can J Public Health 1993;84:254-8.

29 Gomel M, Oldenburg B, Lemon J, Owen N, Westbrook F. Pilot-study of the effects of a workplace smoking ban on indexes of smoking, cigarette craving, stress and other health behaviors. Psychol Health 1993;8:223-9.

30 Hudzinski LG, Frohlich ED. One-year longitudinal study of a no-smoking policy in a medical institution [see comments]. Chest 1990:97:1198-202.

31 Hudzinski LG, Sirois PA. Changes in smoking behavior and body weight after implementation of a no-smoking policy in the workplace. South Med J 1994;87:322-7.

32 Stillman FA, Becker DM, Swank RT, Hantula D, Moses H, Glantz S, et al. Ending smoking at the Johns Hopkins Medical Institutions. An evaluation of smoking prevalence and indoor air pollution. JAMA $1990 ; 254: 1565-9$
33 Becker D, Conner H, Waranch H, Stillman F, Pennington L, Lees P, et al. The impact of a total ban on smoking in the Johns Hopkins Children's Center. JAMA 1989;262:799-802.

34 Centers for Disease Control and Prevention. Evaluation of an employee smoking policy-Pueblo, Colorado. MMWR Morb Mortal Wkly Rep 1990:39:673-6.

35 Gottlieb NH, Eriksen MP, Lovatto CY, Weinstein RP, Green LW. Impact of a restrictive worksite smoking policy on smoking behavior, attitudes, and norms. J Occup Med 1990;32:16-23.

36 Mullooly JP, Schuman KL, Stevens VJ, Glasgow RE, Vogt TM. Smoking behavior and attitudes of employees of a large HMO before and after a work site ban on cigarette smoking. Public Health Rep 1990;105:623-8.

37 Offord KP, Hurt RD, Berge KG, Frusti DK, Schmidt L. Effects of the implementation of a smoking free policy in a medical center. Chest 1992:102:1531-6

38 Tsushima WT, Shimizu AA. Effects of a no-smoking policy upon medical center employees. Int J Addict 1991;26:23-8

39 Baile WF, Gilbertini M, Ulschak F, Snow-Antle S, Hann D. Impact of a hospital smoking ban: changes in tobacco use and employee attitudes. Addict Behav 1991;16:419-26.

40 Daughton DM, Andrews CE, Orona CP, Patil KD, Rennard SI. Total indoor smoking ban and smoker behavior. Prev Med 1992;21:670-6.

41 Olive KE, Ballard JA. Changes in employee smoking behavior after implementation of restrictive smoking policies. South Med J 1996;89:699 706

42 Stave GM, Jackson GW. Effect of a total work-site smoking ban on employee smoking and attitudes. J Occup Med 1991;33:884-90.

43 Rosenstock IM, Stregachis A, Heany C. Evaluation of a smoking prohibition policy in a health maintenance organization. Am J Public Health 1986;76:1014-5.

44 Brenner H, Mielck A. Smoking prohibition in the workplace and smoking cessation in the Federal Republic of Germany. Prev Med 1992;21:252-61.

45 Farelly MC, Evans WN, Sfekas AE. The impact of workplace smoking bans: results from a national survey. Tob Control 1999;8:272-7.

46 Glasgow RE, Cummings KM, Hyland A. Relationship of worksite smoking policies to changes in employee tobacco use: findings from COMMTT. Tob Control 1997;6(suppl 2):S44-8.

47 Kinne S, Kristal A, White E, Hunt J. Work-site smoking policies: their population impact in Washington State. Am J Public Health $1993 ; 83: 1031-3$.

48 Woodruff TJ, Rosbrook B, Peirce J, Glantz SA. Lower levels of cigarette consumption found in smoke-free workplaces in California. Arch Intern Med 1993;153:1485-93.

49 Scott CJ, Gerberich SG. Analysis of a smoking policy in the workplace. AAOHN J 1989;37:265-73.

50 Sorensen G, Rigotti N, Rosen A, Pinney J, Prible R. Effects of a worksite nonsmoking policy: evidence for increased cessation. Am J Public Health 1991;81:202-4.

51 Petersen LR, Helgerson SD, Gibbons CM, Calhoun CR, Pitchford KC. Employee smoking behavior changes and attitudes following a restrictive policy on worksite smoking in a large company. Public Health Rep 1988;103:115-20.

52 Jeffery RW, Kelder SH, Forster JL, French SA, Lando HA, Baxter JE. Restrictive smoking policies in the workplace: effects on smoking prevalence and tobacco consumption. Prev Med 1994;23:78-82.

53 Evans W, Farrelly, MC, Montgomery, E. Do workplace smoking bans reduce smoking? Cambridge, MA: National Bureau of Economic Research, 1996 (Working Paper 5567).

54 Brenner H, Fleischle B. Smoking regulations at the workplace and smoking behavior: a study from Southern Germany. Prev Med 1994;23:230-4

55 Biener L, Nyman A. Effect of workplace smoking policies on smoling cessation: results of a longitudinal study. J Occup Environ Med 1999;41:1121-7.

56 Andrews JL Jr. Reducing smoking in the hospital. An effective model program. Chest 1983;84:206-9.

57 Heloma A, Jaakkola M, Kahkonen E, Reijula K. The short-term impact of national smoke-free workplace legislation on passive smoking and tobacco use. Am J Pub Health 2001;91:1416-8.

58 Shirres G. Successful implementation of a no-smoking policy. Collegian 1996;3:30-8.

59 Paulozzi LJ, Spengler RF, Gower MA. An evaluation of the Vermont worksite smoking law. Public Health Rep 1992;107:724-6.

60 Engstrom P, Rimer B, Mortenson L, eds. The relationship of a worksite no-smoking policy to employee smoking behavior and attitudes. Advances in cancer control. Screening and prevention research. Bethesda, MD: WileyLiss, 1990

61 Rigotti NA, Pashos CL. No-smoking laws in the United States. An analysis of state and city actions to limit smoking in public places and workplaces. JAMA 1991;266:3162-7.

62 Millar WJ. Evaluation of the impact of smoking restrictions in a government setting. Can J Public Health 1988;79:379-82.

63 Batlle E, Boixet M, Agudo A, Almirall J, Salvador T. Tobacco prevention in hospitals: long-term follow-up of a smoking control programme. $\mathrm{Br} \mathrm{J}$ Addict 1991;86:709-17.

64 Patten C, Gilpin E, Cavin S, Pierce J. Workplace smoking policy and changer in smoking behaviour in California: a suggested association. Tob Control 1995;4:36-41.

65 Etter JF, Ronchi A, Perneger T. Short-term impact of a university based smoke free campaign [see comments]. I Epidemiol Community Health 1999;53:710-5.

66 Farkas AJ, Gilpin EA, Distefan JM, Pierce JP. The effects of household and workplace smoking restrictions on quitting behaviours. Tob Control 1999;8:261-5.

67 Gerlach KK, Shopland DR, Hartman AM, Gibson JT, Pechacek TF. Workplace smoking policies in the United States: results from a national survey of more than 100,000 workers. Tob Control 1997;6:199-206. 
68 Goldstein AO, Westbrook WR, Howell RE, Fischer PM. Hospital efforts in smoking control: remaining barriers and challenges. J Fam Pract 1992;34:729-34.

69 Longo DR, Brownson RC, Johnson JC, Hewett JE, Kruse RL, Novotny TE, et al. Hospital smoking bans and employee smoking behavior: results of a national survey. JAMA 1996;275:1252-7.

70 Owen N, Borland R. Delayed compensatory cigarette consumption after a workplace smoking ban. Tob Control 1997;6:131-5.

71 Pederson LL, Bull SB, Ashley MJ, Garcia JM, Lefcoe NM. An evaluation of the workplace smoking bylaw in the city of Toronto. Am J Public Healt 1993;83:1342-5

72 Wakefield MA, Wilson D, Owen N, Esterman A, Roberts L. Workplace smoking restrictions, occupational status, and reduced cigarette consumption.J Occup Med 1992:34:693-7.

73 Longo DR, Johnson JC, Kruse RL, Brownson RC, Hewett JE. A prospective investigation of the impact of smoking bans on tobacco cessation and relapse. Tob Control 2001;10:267-72.

74 Emont SL, Zahniser SC, Marcus SE, Trontell AE, Mills S, Frazier EL, et al. Evaluation of the 1990 Centers for Disease Control and Prevention smoke-free policy. Am J Health Promot 1995;9:456-61.

75 Cooreman J, Mesbah H, Leynaert B, Segala C, Pretet S. Evaluation of the impact of a smoking ban in a large Paris hospital. Semaine des Hopitaux 1997;73:317-23.

76 Sutton A, Abrams K, Jones D, Sheldon T, Song F. Methods for meta-analysis in medical research. Chichester: John Wiley, 2000.

77 Petitti D. Meta-analysis, decision analysis, and cost-effectiveness analysis. $2 \mathrm{nd}$ ed New York: Oxford University Press, 2000.

78 US Bureau of the Census. Resident population of the United States by age and sex. www.census.gov/population/estimates/nation/intfile2-1.txt (accessed 17 Aug 2001)

79 US Bureau of Labor Statistics. National employment and wage estimates, www.bls.gov/oes/1999/oes_nat.htm (accessed 17 Aug 2001).

80 Lader D, Meltzer H. Smoking related behaviour and attitudes, 1999. London: Office for National Statistics, 2000.

81 Orzechowski W, Walker R. The tax burden on tobacco. Arlington, VA: Orzechowski and Walker, 2000.

82 Office for National Statistics. Mid-2000 UK population estimates www.statistics.gov.uk/pdfdir/pop0801.pdf (accessed 21 August 2001).

83 Centers for Disease Control. Percentage of adults who were current, former or never smokers, overall and by sex, race, Hispanic origin, National Health Interview Surveys, selected years-United States, 1965-1995. www.cdc.gov/tobacco/research_data/adults_prev/ adstat1.htm (accessed 20 Aug 2001).

84 Chaloupka F. Clean indoor air laws, addiction and cigarette smoking. Appl Econ 1992;24:193-205.

85 Chaloupka F, Saffer H. Clean indoor air laws and the demand for cigarettes. Contemporary Policy Issues 1992;10:72-83.

86 Moskowitz JM, Lin Z, Hudes ES. The impact of workplace smoking ordinances in California on smoking cessation. Am J Public Healt 2000;90:757-61.

87 Emont S, Choi W, Novotny T, Giovina G. Clean indoor air legislation, taxation and smoking behavior in the United States: an ecological analysis. Tob Control 1992:2:13-7.

88 Yurekli AA, Zhang P. The impact of clean indoor air laws and cigarette smuggling on demand for cigarettes: an empirical model. Health Econ 2000;9:159-70.

89 Stephens T, Pederson LL, Koval JJ, Kim C. The relationship of cigarette prices and no-smoking bylaws to the prevalence of smoking in Canada. Am J Public Health 1997;87:1519-21.
90 Wasserman J, Manning WG, Newhouse JP, Winkler JD. The effects of excise taxes and regulations on cigarette smoking. $J$ Health Econ 1991;10:43-64.

91 National Cancer Institute. Major local tobacco control ordinances in the United States. Bethesda, MD: USDHHS, 1993 (Smoking and Tobacco Control Monograph 3).

92 Farkas AJ, Gilpin EA, White MM, Pierce JP. Association between household and workplace smoking restrictions and adolescent smoking. JAMA 2000;284:717-22.

93 Chaloupka FJ, Wechsler H. Price, tobacco control policies, and smoking among young adults. J Health Econ 1997;16:359-73.

94 Chaloupka F, Grossman M. Price, tobacco control policies and youth smoking. Cambridge, MA: National Bureau of Economic Research, 1996 (Working Paper 5740)

95 Gruber J. Youth smoking in the US: prices and policies. Cambridge, MA National Bureau of Economic Research, 2000.

96 Lewit E, Hyland A, Kerrebrock N, Cummings K. Price, public policy and smoking in young people. Tob Control 1997;6(suppl 2):S17-24.

97 Wakefield MA, Chaloupka FJ Kaufman NT, Orleans CT, Barker DC, Ruel EE. Effect of restrictions at home, at school, and in public places on teenage smoking: cross sectional study. BMJ 2000;321:333-7.

98 Tauras J, Chaloupka F. Price, clean indoor air laws, and cigarette smoking: evidence from longitudinal data for young adults. Cambridge, MA: National Bureau of Economic Research, 1999.

99 Chaloupka FJ, Pacula RL. Sex and race differences in young people's responsiveness to price and tobacco control policies. Tob Control 1999:8:373-7.

100 Glantz SA, Jamieson P. Attitudes toward secondhand smoke, smoking, and quitting among young people. Pediatrics 2000;106:E82.

101 Fichtenberg CM, Glantz SA. Youth access interventions do not affect youth smoking. Pediatrics 2002;109:1088-92.

102 US Department of Health and Human Services. Reducing the health consequences of smoking: 25 years of progress. A report of the surgeon general. Rockville, MD: US Deparment of Health and Human Services, Centers for Disease Control and Prevention, National Center for Chronic Disease Prevention and Health Promotion, Office of Smoking and Health, 1989.

103 Hymowitz N, Cummings KM, Hyland A, Lynn WR, Pechacek TF, Hartwell TD. Predictors of smoking cessation in a cohort of adult smokers followed for five years. Tob Control 1997;6(suppl 2):S57-62.

104 Abernathy T, O'Grady B, Dukeshire S. Changes in ETS following anti-smoking legislation. Can J Pub Health 1998;89:33-4.

105 Eisner MD, Smith AK, Blanc P. Bartenders' respiratory health after establishment of smoke-free bars and taverns. JAMA 1998;280:1909-14.

106 Samuels B, Glantz SA. The politics of local tobacco control. JAMA 1991;266:2110-7.

107 Traynor MP, Begay ME, Glantz SA. New tobacco industry strategy to prevent local tobacco control. JAMA 1993;270:479-86.

108 Magzamen S, Glantz SA. The new battleground: California's experience with smoke-free bars. Am J Public Health 2001;91:245-52.

109 Mangurian CV, Bero LA. Lessons learned from the tobacco industry's efforts to prevent the passage of a workplace smoking regulation. $A m J$ Public Health 2000;90:1926-30.

110 Project Down Under. Conference Notes. Phillip Morris, 24 June, 1987: Bates Range 2021502102/2134 www.pmdocs.com/PDF/ 2021502102_2134.PDF (accessed 27 Oct 2001).

(Accepted 21 March 2002) 